\section{'L-93' Creeping Bentgrass Putting Green Responses to Various Winter Light Intensities in the Southern Transition Zone}

\author{
Christian M. Baldwin \\ Jacklin Seed by Simplot, 5300 West Riverbend Avenue, Post Falls, ID 83854 \\ Haibo Liu ${ }^{1}$ and Lambert B. McCarty \\ Department of Horticulture, 253 P and A Building, Clemson University, \\ Clemson, SC 29634-0319
}

\section{Hong Luo \\ Department of Genetics and Biochemistry, Clemson University, Clemson, SC 29634-0318}

Joe E. Toler

Department of Applied Economics and Statistics, Clemson University, Clemson, SC 29634-0318

Additional index words. shade, shade tolerance, turfgrass, golf course

\begin{abstract}
Seasonal variations in temperature and solar radiation in the warm climatic region of the transition zone increase difficulty of creeping bentgrass [Agrostis stolonifera var. palustris (Huds.)] management throughout the year. The impact of winter shade on bentgrass quality and subsequent residual effects of winter shade in spring and summer months has not been investigated. Therefore, a 2-year field study investigated trinexapacethyl (TE) [4-(cyclopropyl- $\alpha$-hydroxy-methylene)-3,5-dioxy-cyclohexanecarboxylic acid ethyl ester] as a winter management strategy to alleviate winter shade stress and determined the winter shade tolerance of ' $L-93$ ' creeping bentgrass under various reduced light environments. Treatments included a full-sunlight control; $58 \%$ and $96 \%$ morning, afternoon, and full-day shade artificial; and TE (0.02 kg a.i./ha) applied every 2 weeks from December to July. Data collection included daily light measurements (photosynthetic photon flux density), monthly canopy and soil temperatures, visual turfgrass quality (TQ), chlorophyll concentration, clipping yield, total root biomass, and total root nonstructural carbohydrates. Under $96 \%$ shade, canopy temperatures were reduced $\approx \mathbf{5 7 \%}$ from December to February, whereas soil temperatures were reduced $39 \%$ in February compared with full sunlight. Afternoon shade (58\%) maintained acceptable TQ throughout winter for both years. Applying TE every 2 weeks in the winter negatively impacted bentgrass quality; however, TE enhanced spring and summer quality. Morning or afternoon shade minimally impacted parameters measured. Overall, moderate winter shade may not limit ' $L-93$ ' creeping bentgrass performance as a putting green in the transition zone. Results suggest winter shade does not contribute to creeping bentgrass summer decline because all shade-treated plots fully recovered from shade damage in spring months.
\end{abstract}

Creeping bentgrass [Agrostis stolonifera var. palustris (Huds.)], a $\mathrm{C}_{3}$ plant, is widely used as a putting green turfgrass in cooler climate areas and the transition zone (McCarty, 2005). However, as a result of seasonal temperature variation, creeping

Received for publication 3 Apr. 2009. Accepted for publication 7 July 2009

This research was supported by USGA Green Section, South Carolina Turfgrass Foundation, and Clemson University.

We thank Dr. Wes Totten, Mr. William Sarvis, Mr. Philip Brown, and Mr. Steve Long for their assistance during the study.

${ }^{1}$ To whom reprint requests should be addressed; e-mail haiboL@clemson.edu. bentgrass putting greens face many environmental stresses and agronomic challenges year round, including shade. Cool-season turfgrass decline in severe shade is partially attributed to increased disease pressure (Beard, 1965, 1969; Vargas and Beard, 1981), because tree water transpiration is greatest at night, extending dew duration on turf (Williams et al., 1996, 1998). Management strategies to combat shade stress include raising the height of mowing (Bunnell et al., 2005b; White, 2004), reducing nitrogen $(\mathrm{N})$ input (Baldwin et al., 2009; Bunnell et al., 2005b; Goss et al., 2002), applying plant growth regulators (PGRs) (Baldwin et al., 2009; Bunnell et al., 2005b; Ervin et al., 2004; Qian and Engelke, 1999; Qian et al., 1998; Stier and Rogers, 2001), and watering deeply and infrequently (Dudeck and Peacock, 1992).

Trinexapac-ethyl (TE, Primo Maxx; Syngenta Chem Co., Greensboro, NC) effectively inhibits gibberellic acid (GA) $\left(\mathrm{GA}_{20}\right.$ to $\mathrm{GA}_{1}$ ) production (Adams et al., 1992) late in the mevalonic acid pathway suppressing shoot vertical growth. In kentucky bluegrass (Poa pratensis L.) cultivars, TE $(0.048 \mathrm{~kg}$ a.i./ha) reduced $\mathrm{GA}_{1} 49 \%$ and increased $\mathrm{GA}_{20} 146 \%$ under $87 \%$ shade (Tan and Qian, 2003). As a result of GA disruption, TE typically enhances warm- and cool-season turfgrass quality when light interception is interrupted.

'Penncross' creeping bentgrass grown under $80 \%$ shade treated with multiple TE applications at 0.042 and $0.070 \mathrm{~kg}$ a.i./ha increased fructose concentration $\approx 39 \%$ with minimal effects on other carbohydrate constituents (Goss et al., 2002). Similarly, Steinke and Stier (2003) noted TE applied monthly and bimonthly enhanced 'Penncross' creeping bentgrass TQ and chlorophyll concentration under $80 \%$ shade. It appears that consistent TE applications is an effective management strategy to reduce shade damage. However, Gardner and Wherley (2005) noted a turfgrass quality (TQ) decline for tall fescue (Festuca arundinacea Schreb. 'Plantation'), rough bluegrass (Poa trivialis L.), and sheep fescue (Festuca ovina L.) and density decline in tall fescue and rough bluegrass grown under Acer saccharinum L. and Platanus occidentalis L. trees $(91 \%$ light reduction) 4 to 6 weeks after TE (0.29 $\mathrm{kg}$ a.i./ha) applications.

Although morning shade is perceived as more detrimental than afternoon shade for warm- and cool-season turfgrass growth, few experiments have investigated this observation. Bell and Danneberger (1999) noted shade duration was more detrimental than timing of shade for 'Penncross' creeping bentgrass. However, a warm-season putting green turfgrass, 'TifEagle' bermudagrass [Cynodon dactylon $(\mathrm{L}$.) Pers. $\times$ C. transvaalensis], declined more readily in the absence of afternoon solar irradiance (Bunnell et al., 2005a).

In the transition zone, creeping bentgrass putting green summer decline is the result of a combination of stresses, which includes high soil and atmosphere temperatures $(\mathrm{Xu}$ and Huang, 2000, 2001), elevated soil $\mathrm{CO}_{2}$ levels (Bunnell et al., 2002; Rodriguez et al., 2005), high summer disease potential (Dernoeden, 2002), and increased day and night temperatures (Fu and Huang, 2003; Huang and Gao, 2000). Management practices to combat these stresses are well documented (Bunnell et al., 2004; Feng et al., 2002; Guertal et al., 2005; Liu and Huang, 2003). However, there is a lack of information in the literature and it is currently unknown whether winter shade on a creeping bentgrass putting green is a stressful factor or a contributing factor to creeping bentgrass summer decline because golf courses are in service in winter months in the transition zone. Shade stress is typically considered most problematic during summer months when trees are full of leaves. 
Winter shade may be potentially damaging as a result of shorter photoperiods, reduced light intensities, solar elevation angles, and extended frost accumulation. For example, solar light intensity in the eastern part of the transition zone ranges from less than 300 (winter) to greater than $1800 \mu \mathrm{mol} \cdot \mathrm{m}^{-2} \cdot \mathrm{s}^{-1}$ (summer) (Baldwin et al., 2008). Also, each year, there is a range of 20 to 30 frost events in which soil/surface temperatures can vary from below $\approx 0$ to $20{ }^{\circ} \mathrm{C}$ (Baldwin et al., 2008). Lower solar angles and evergreen trees during winter months can cause severe winter month-only shade depending on the orientation and location of a putting green. Creeping bentgrass putting green responses to winter shade impacts in the transition zone and management recommendations to minimize shade stress have yet to be investigated. Also, winter shade effects on spring and summer performance are lacking. Therefore, research objectives were to 1) investigate 'L-93' creeping bentgrass putting green responses to two levels of winter light reduction of $58 \%$ and $96 \%$ with variation of morning, afternoon, or full-day shade; 2) identify whether TE is effective to reduce winter shade stress; and 3 ) determine any residual effects of winter month shade on spring and summer turf quality and performance.

\section{Materials and Methods}

This research was conducted at the Turfgrass Research Center, Clemson University, Clemson, SC, on a 'L-93' creeping bentgrass field research green established in Aug. 2002 with soil profile constructed to U.S. Golf Association (USGA) recommendations (USGA Green Section Staff, 1993). Artificial light intensity treatments were initiated 1 Dec. 2004 and ended 28 Feb. 2005 and repeated during the subsequent winter. Data collection was continued through July each year to determine any residual effects of treatments on spring and summer bentgrass performance. Light intensity treatments consisted of a control (full sunlight) and $58 \%$ and 96\% light reduction in morning, afternoon, and full-day intervals using a neutral density, polyfiber black shadecloth (Glenn Harp and Sons, Inc., Tucker, GA) supported by polyvinyl chloride (PVC) $183 \mathrm{~cm}$ in length and $152 \mathrm{~cm}$ in width with 2.54-cm-diameter PVC pipes. Shade structures were placed $15 \mathrm{~cm}$ above the bentgrass surface to reduce early morning and late afternoon sunlight encroachment, yet maintain adequate air movement. By a pre-experiment comparison (data not shown), there was no temperature increase under any shade structures regardless of the structure height from $15 \mathrm{~cm}$ to 45 $\mathrm{cm}$. For morning shade, structures were placed over the bentgrass surface at sunrise and removed at solar noon. For afternoon shade, structures were placed over the bentgrass surface at solar noon and removed at sunset. For full-day shade, structures were placed over the bentgrass surface at sunrise and removed at sunset. Regardless of shade treatment, all structures were removed every evening because a 15 -cm-high shade structure would significantly change the dew or frost cover on the research green if not removed nightly.

Trinexapac-ethyl was applied at $0.02 \mathrm{~kg}$ a.i./ha every 2 weeks using the emulsifiable concentrate $\left(11.3 \%\right.$ a.i.) with a $\mathrm{CO}_{2}$-pressurized backpack sprayer calibrated at 1010 $\mathrm{L} \cdot \mathrm{ha}^{-1}$ beginning $1 \mathrm{Dec}$. through 31 July each year. The bentgrass green was mowed at a $3.2-\mathrm{mm}$ height two to four times weekly during winter months depending on weather conditions with clippings removed. During spring, summer, and fall, mowing $(3.2 \mathrm{~mm})$ occurred six to seven times weekly. A combination of $10 \mathrm{~N}-1.3 \mathrm{P}-4.2 \mathrm{~K}$ and $5 \mathrm{~N}-0 \mathrm{P}-$ $5.8 \mathrm{~K}$ liquid fertilizers $(50: 50$ in the quantity of N) (Progressive Turf, LLC., Ball Ground, GA) was applied overall plots early Jan. 2005 and 2006 at a rate of $4.9 \mathrm{~kg} \mathrm{~N} / \mathrm{ha}$. In spring, $9.7 \mathrm{~kg} \mathrm{~N} / \mathrm{ha}$ every 2 weeks was applied overall plots using Progressive Turf liquid fertilizer, whereas in summer, the same liquid fertilizer $(10-1.3 \mathrm{P}-4.2 \mathrm{~K}$ and $5-0 \mathrm{P}-5.8 \mathrm{~K})$ was applied at $4.9 \mathrm{~kg} \mathrm{~N} /$ ha every 2 weeks. In fall, $9.7 \mathrm{~kg} \mathrm{~N} /$ ha every 2 weeks was applied overall plots using liquid fertilizers $(10 \mathrm{~N}-$ $1.3 \mathrm{P}-4.2 \mathrm{~K}$ and $5 \mathrm{~N}-0 \mathrm{P}-5.8 \mathrm{~K})$. Hollow tine aerification $(1.3-\mathrm{cm}$-diameter tines $10 \mathrm{~cm}$ in length with $5.0-\mathrm{cm}$ spacing) occurred twice in the spring and once in the fall. After cultivation, $24.4 \mathrm{~kg} \mathrm{~N} / \mathrm{ha}$ was applied overall plots using $18 \mathrm{~N}-1.3 \mathrm{P}-14.9 \mathrm{~K}$ greens-grade granular fertilizer (Anderson's, Maumee, $\mathrm{OH})$. Disease occurrence in winter was minimal; therefore, no fungicides were applied. In summer, chlorothalonil (Daconil; Syngenta) (11.8 L·ha), azoxystrobin (Heritage; Syngenta) (48 kg a.i./ha), and mefonoxam (Subdue MAXX; Syngenta) $\left(6.4 \mathrm{~L} \cdot \mathrm{ha}^{-1}\right)$ were applied as needed for dollar spot (Sclerotinia homoeocarpa F.T. Bennet), pythium diseases (Pythium spp.), and brown patch (Rhizoctonia solani Kuhn.) control, respectively. The bentgrass green did not receive additional topdressing except one after each of the three core aerifications annually.

Data collection. Data collected included microenvironment conditions, visual TQ, clipping yield, chlorophyll concentration, total root biomass, and root total non-structural carbohydrates (TNC).

Microenvironment parameters included surface and soil temperature, air movement, and light quality and quantity. Surface and soil temperature was recorded four times weekly during winter months at solar noon for one full-sunlight plot and under one $58 \%$ and $96 \%$ shadecloth using a thermometer (Model \#1455 and Model \#9840; Taylor, Oakbrook, IL). Sensors for canopy temperature were placed on the surface, whereas soil temperatures were recorded at a $7.6-\mathrm{cm}$ depth. Air movement was recorded twice on days with a consistent breeze using an anemometer (Model \#CS-800; Clark Solutions, Hudson, MA). Light quality was measured on a clear, cloudless day at solar noon using a spectroradiameter (Model LI-1800; LI-COR, Inc., Lincoln, NE), whereas photon flux density $\left(\mu \mathrm{mol} \cdot \mathrm{m}^{-2} \cdot \mathrm{s}^{-1}\right)$ was recorded four times weekly during winter months at solar noon for one full-sunlight plot and under one $58 \%$ and $96 \%$ shadecloth using a quantum radiometer (Model LI-250; LI-COR, Inc.).

Visual TQ ratings were measured monthly based on color, density, texture, and uniformity of the 'L-93' creeping bentgrass surface. Quality was visually evaluated from 1 to 9 with $1=$ brown, dead turfgrass, $6=$ minimal acceptable turfgrass, and $9=$ ideal green, healthy turfgrass.

Clipping yield $\left(\mathrm{g} \cdot \mathrm{m}^{-2}\right)$ was collected midJanuary, late-February, and mid-May for both years. Shoot tissue was collected using a walk-behind greens mower (Greenmaster ${ }^{\circledR}$ 800; The Toro Company, Bloomington, $\mathrm{MN}$ ) after $3 \mathrm{~d}$ of growth. Clippings were ovendried at $80{ }^{\circ} \mathrm{C}$ for $48 \mathrm{~h}$ and weighed to quantify shoot production.

Chlorophyll concentration $\left(\mathrm{mg} \cdot \mathrm{g}^{-1}\right)$ was determined on the same dates as clipping yield. Fresh clippings were collected (as described previously) from each plot and immediately placed in a plastic bag inside a covered bucket to prevent sunlight degradation. Clippings were weighed $(0.1 \mathrm{~g})$ and placed in a glass test tube $(1.0 \mathrm{~cm}$ in width and $14.8 \mathrm{~cm}$ in length) with $10 \mathrm{~mL}$ of dimethyl sulfoxide, which eliminates shoot tissue grinding to extract chlorophyll (Hiscox and Israelstam, 1979). Samples were incubated in $65^{\circ} \mathrm{C}$ water on a hot plate (PC-600; Corning, Corning, NY) for $1.5 \mathrm{~h}$ and continuously shaken. On completion, samples were passed through filter paper (Whatman 41, Whatman, U.K.) and remaining extract $(2 \mathrm{~mL})$ transferred into cuvettes. Absorbance values were recorded at $663-\mathrm{nm}$ and 645-nm wavelengths using a spectrophotometer (Genesys ${ }^{\mathrm{TM}}$ 20; ThermoSpectronic, Rochester, NY). Blanks were initially run and also after every sixth sample. The following formula was used to calculate total chlorophyll: $\mathrm{mg} \cdot \mathrm{g}^{-1}=\left(8.02 * \mathrm{D}_{663}+20.2\right.$ $\left.* \mathrm{D}_{645}\right) * 0.1$ (Arnon, 1949).

Roots were extracted from the soil using a cylinder core sampler $(7.5 \mathrm{~cm}$ in diameter by $30 \mathrm{~cm}$ deep) $15 \mathrm{Jan}$. and $28 \mathrm{Feb}$. for both years. One plug was randomly sampled from each plot and refilled with the same root zone sand mix (85:15 sand:peatmoss; v:v). Once all soil was completely removed from each soil plug using tap water over a $1-\mathrm{mm}$ sieve, roots were clipped from the shoot tissue base and placed in an oven $\left(80.0^{\circ} \mathrm{C}\right)$ for $48 \mathrm{~h}$ and then weighed.

Root TNC (mg. $\left.\mathrm{g}^{-1}\right)$ was collected at the end of February for both years. Root tissue was harvested using a bulk density sampler, which extracted $206-\mathrm{cm}^{3}$ (10.2 $\mathrm{cm}$ in depth) cores before sunrise to minimize potential diurnal fluctuations (Westhafer et al., 1982). Root TNC was analyzed using Nelson's Assay (Nelson, 1944), which determines glucose and fructose in plant tissue (Nelson, 1944; Somogyi, 1952). For detailed methodology, consult Waltz and Whitwell (2005).

Data analysis. Treatment factors were arranged in a split-block design with four replications. Light treatments (morning, afternoon, full-day shade at two levels of 
$58 \%$ and $96 \%$ light reduction) were arranged in a randomized complete block design, whereas TE was the split factor. Treatment effects were evaluated using analysis of variance within SAS (Version 9.1; SAS Institute, Cary, NC). No treatment-by-TE interactions occurred for any parameters; therefore, marginal means for light treatments and TE are explained separately. For TQ scores, year-bytreatment interactions occurred in January, February, or March; therefore, yearly results are presented separately. For chlorophyll and clipping yield, year-by-treatment interactions occurred in January; therefore, yearly results are presented separately. All other parameters showed no significant treatment-by-year interactions; therefore, yearly data were pooled. Means separation was performed using Fisher's protected least significant difference test with $\alpha=0.05$.

\section{Results}

Microenvironment. Light intensity was reduced by $58 \%$ and $96 \%$ by the shade cloths relative to full sunlight (Table 1). Full-day $58 \%$ and $96 \%$ shade reduced canopy temperatures $\approx 28 \%$ and $\approx 57 \%$, respectively, each month compared with full sunlight. In December and February, full-day shade (96\%) reduced soil temperatures $\approx 43 \%$ compared with full sunlight. Also, coldest surface and soil temperatures occurred in December followed by a gradual warming trend in January and February. Light quality and air movement were unaffected by shade cloths and/or structures (data not shown).

Turfgrass quality. One month after shade treatment initiation, significant differences were noted between shade treatments (Table 2). In December, full-day 96\% shade had the highest TQ (7.4) compared with all other treatments; however, this response was transient in Year 1. In Year 2, by January (4.9) and February (4.2), full-day $96 \%$ shade had the lowest TQ scores compared with all other treatments. No differences were detected between morning and afternoon shade in December. In January (Year 1), afternoon shade (58\%) TQ was 0.6 rating units higher compared with morning shade $(58 \%)$; however, this difference was not detected in January (Year 2) or in February for either year. Differences were not detected between full-day and diurnal 58\% shade in January (Winter 1); however, afternoon 58\% shade TQ was 0.6 rating units higher compared with full-day $58 \%$ shade. In January (Year 1), morning and afternoon shade (96\%) TQ was $\approx 1.9$ rating units higher compared with full-day $96 \%$ shade. Similarly, in February (Year 1), full-day $96 \%$ shade TQ was $\approx 2.1$ units lower compared with morning and afternoon $96 \%$ shade.

In Year 2, full-day $96 \%$ shade remained above the acceptable TQ threshold of 6 through January and February (Table 2). No differences were detected between morning and afternoon shade for either shade intensity. In January and February (Year 2), fullday $58 \%$ shade TQ was $\approx 0.8$ and $\approx 1.0$ rating units higher than morning or afternoon $58 \%$ shade, respectively. Full-day $96 \%$ shade TQ was $\approx 0.7$ units higher than $96 \%$ morning or afternoon shade in January (Year 2).

Applying TE every 2 weeks did not impact TQ scores in December or January (Table 2). However, apply TE decreased TQ $\approx 0.6$ rating units in February (Years 1 and 2 ) compared with TE-treated plots.

In March (Year 1), 96\% afternoon shade TQ was 0.8 rating units higher compared with morning 96\% shade; however, no morning or afternoon TQ variations were noted under $58 \%$ shade (Table 3). Regardless, full-day $96 \%$ shade had the lowest TQ (4.3) compared with other treatments in March (after Year 1).

Table 1. Winter surface and soil temperatures $\left({ }^{\circ} \mathrm{C}\right)$ recorded at solar noon four times weekly from 1 Dec. to 28 Feb. in Years 1 and 2.

\begin{tabular}{|c|c|c|c|c|c|c|}
\hline \multirow{3}{*}{$\begin{array}{l}\text { Treatment } \\
\text { factor } \\
\text { Shade }\end{array}$} & \multicolumn{6}{|c|}{ Surface and soil temp $\left({ }^{\circ} \mathrm{C}\right)$} \\
\hline & \multicolumn{2}{|c|}{ December } & \multicolumn{2}{|c|}{ January } & \multicolumn{2}{|c|}{ February } \\
\hline & Surface & Soil & Surface & Soil & Surface & Soil \\
\hline None & 17.3 & 5.7 & 20.8 & 8.4 & 22.8 & 8.5 \\
\hline $58 \%$ full day & 13.2 & 4.3 & 16.7 & 7.3 & 18.0 & 6.9 \\
\hline $96 \%$ full day & 10.8 & 3.9 & 14.0 & 6.8 & 14.1 & 6.1 \\
\hline
\end{tabular}

Table 2. Turfgrass quality of 'L-93' creeping bentgrass in December, January, and February in response to full sunlight and 58\% and 96\% morning, afternoon, and full-day winter shade (month of December to February from 2004 to 2006) and trinexapac-ethyl (TE; $0.02 \mathrm{~kg} \cdot \mathrm{ha}^{-1}$ ) applications every 2 weeks from 1 Dec. to 31 July 2004 to 2006.

\begin{tabular}{|c|c|c|c|c|c|}
\hline \multirow{2}{*}{$\begin{array}{l}\text { Treatment factor } \\
\text { Shade }\end{array}$} & \multirow{2}{*}{$\frac{\text { Years } 1 \text { and } 2}{\text { December }^{z}}$} & \multicolumn{2}{|c|}{ Year 1} & \multicolumn{2}{|c|}{ Year 2} \\
\hline & & January & February & January & February \\
\hline Control & $5.7 \mathrm{~d}^{\mathrm{y}}$ & $6.8 \mathrm{ab}$ & $5.5 \mathrm{c}$ & $5.2 \mathrm{~d}$ & $5.1 \mathrm{c}$ \\
\hline $58 \%$ morning & $6.3 \mathrm{c}$ & $6.7 \mathrm{~b}$ & $6.2 \mathrm{ab}$ & $5.5 \mathrm{~d}$ & $5.3 \mathrm{bc}$ \\
\hline $58 \%$ afternoon & $6.5 \mathrm{c}$ & $7.3 \mathrm{a}$ & $6.6 \mathrm{a}$ & $5.7 \mathrm{~cd}$ & $5.4 \mathrm{bc}$ \\
\hline $58 \%$ full day & $6.7 \mathrm{~b}$ & $6.8 \mathrm{ab}$ & $6.0 \mathrm{bc}$ & $6.4 \mathrm{ab}$ & $6.3 \mathrm{a}$ \\
\hline $96 \%$ morning & $6.7 \mathrm{~b}$ & $6.7 \mathrm{~b}$ & $6.0 \mathrm{bc}$ & $6.1 \mathrm{bc}$ & $6.1 \mathrm{a}$ \\
\hline $96 \%$ afternoon & $6.8 \mathrm{~b}$ & $6.8 \mathrm{ab}$ & $6.6 \mathrm{a}$ & $6.1 \mathrm{bc}$ & $5.9 \mathrm{ab}$ \\
\hline $96 \%$ full day & $7.4 \mathrm{a}$ & $4.9 \mathrm{c}$ & $4.2 \mathrm{~d}$ & $6.8 \mathrm{a}$ & $6.3 \mathrm{a}$ \\
\hline \multicolumn{6}{|l|}{ TE } \\
\hline 0 & 6.6 & 6.6 & $6.2 \mathrm{a}$ & 6.1 & $6.0 \mathrm{a}$ \\
\hline 0.02 & 6.5 & 6.5 & $5.5 \mathrm{~b}$ & 5.9 & $5.5 \mathrm{~b}$ \\
\hline
\end{tabular}

${ }^{\mathrm{z}}$ No treatment-by-year interaction occurred; therefore, data from each winter are pooled.

${ }^{y}$ Values in a column within each treatment factor followed by the same letter are not significantly different at $P \leq 0.05$ by protected least significant difference.

Turfgrass quality based on a scale of 1 to 9 with $1=$ brown/dead turfgrass, $6=$ minimally acceptable turfgrass, and $9=$ healthy/green turfgrass.

Table 3. Turfgrass quality of 'L-93' creeping bentgrass in spring and summer in response to full sunlight and 58\% and 96\% morning, afternoon, and full-day winter shade (month of December to February in 2004 to 2006) and trinexapac-ethyl (TE; $0.02 \mathrm{~kg} \cdot \mathrm{ha}^{-1}$ ) applications every 2 weeks from 1 Dec. to 31 July 2004 to 2006.

\begin{tabular}{|c|c|c|c|c|c|c|}
\hline \multirow{2}{*}{$\begin{array}{l}\text { Treatment factor } \\
\text { Shade }\end{array}$} & Year 1 & Year 2 & \multicolumn{4}{|c|}{ Years 1 and 2} \\
\hline & \multicolumn{2}{|c|}{ March } & April $^{z}$ & May $^{z}$ & June $^{z}$ & July $^{z}$ \\
\hline None & $5.3 \mathrm{~b}^{\mathrm{y}}$ & 5.5 & 6.7 & $7.1 \mathrm{ab}$ & $7.5 \mathrm{c}$ & $6.6 \mathrm{a}$ \\
\hline $58 \%$ morning & $5.7 \mathrm{ab}$ & 6.0 & 6.8 & $7.1 \mathrm{ab}$ & $7.6 \mathrm{ab}$ & $6.4 \mathrm{ab}$ \\
\hline $58 \%$ afternoon & $5.8 \mathrm{ab}$ & 6.2 & 7.1 & $7.5 \mathrm{a}$ & $7.8 \mathrm{a}$ & $6.2 \mathrm{~b}$ \\
\hline $58 \%$ full day & $5.5 \mathrm{ab}$ & 6.4 & 6.8 & $7.4 \mathrm{a}$ & $7.5 \mathrm{ab}$ & $6.5 \mathrm{a}$ \\
\hline $96 \%$ morning & $5.3 \mathrm{~b}$ & 6.0 & 6.7 & $7.2 \mathrm{ab}$ & $7.4 \mathrm{c}$ & $6.2 \mathrm{~b}$ \\
\hline $96 \%$ afternoon & $6.1 \mathrm{a}$ & 6.1 & 7.0 & $7.2 \mathrm{ab}$ & $7.4 \mathrm{c}$ & $6.6 \mathrm{a}$ \\
\hline $96 \%$ full day & $4.3 \mathrm{c}$ & 6.3 & 6.9 & $6.9 \mathrm{~b}$ & $7.5 \mathrm{bc}$ & $6.6 \mathrm{a}$ \\
\hline \multicolumn{7}{|l|}{ TE } \\
\hline 0 & 5.5 & $6.2 \mathrm{a}$ & 6.7 & $6.9 \mathrm{~b}$ & $7.4 \mathrm{~b}$ & 6.4 \\
\hline 0.02 & 5.5 & $5.9 \mathrm{~b}$ & 6.9 & $7.5 \mathrm{a}$ & $7.6 \mathrm{a}$ & 6.4 \\
\hline
\end{tabular}

${ }^{2}$ No treatment-by-year interaction occurred; therefore, data from each year are pooled.

${ }^{y}$ Values in a column within each treatment factor followed by the same letter are not significantly different at $P \leq 0.05$ by protected least significant difference.

Turfgrass quality based on a scale of 1 to 9 with 1 = brown/dead turfgrass, $6=$ minimally acceptable turfgrass, and $9=$ healthy/green turfgrass. 
Table 4. Chlorophyll concentration ( $\left.\mathrm{mg} \cdot \mathrm{g}^{-1}\right)$ of 'L-93' creeping bentgrass in January, February, and May in response to full sunlight and 58\% and $96 \%$ morning, afternoon, and full-day winter shade (December to February, 2004 to 2006) and trinexapac-ethyl (TE; $0.02 \mathrm{~kg} \cdot \mathrm{ha}^{-1}$ ) applications every 2 weeks from 1 Dec. to 31 July 2004 to 2006.

\begin{tabular}{|c|c|c|c|c|}
\hline \multirow{2}{*}{$\begin{array}{l}\text { Treatment factor } \\
\text { Shade }\end{array}$} & Year 1 & Year 2 & \multicolumn{2}{|c|}{ Years 1 and 2} \\
\hline & \multicolumn{2}{|c|}{ January } & Februaryz & May $^{z}$ \\
\hline None & $2.5 b^{y}$ & $1.5 \mathrm{~d}$ & $2.0 \mathrm{~d}$ & 2.4 \\
\hline $58 \%$ morning & $2.4 \mathrm{~b}$ & $1.6 \mathrm{~cd}$ & $2.1 \mathrm{~cd}$ & 2.4 \\
\hline $58 \%$ afternoon & $3.0 \mathrm{a}$ & $1.6 \mathrm{~b}-\mathrm{d}$ & $2.1 \mathrm{~cd}$ & 2.5 \\
\hline $58 \%$ full day & $2.7 \mathrm{ab}$ & $1.7 \mathrm{bc}$ & $2.2 \mathrm{bc}$ & 2.3 \\
\hline $96 \%$ morning & $2.5 \mathrm{~b}$ & $1.8 \mathrm{~b}$ & $2.2 \mathrm{bc}$ & 2.4 \\
\hline $96 \%$ afternoon & $2.6 \mathrm{ab}$ & $1.8 \mathrm{~b}$ & $2.3 \mathrm{~b}$ & 2.4 \\
\hline $96 \%$ full day & $2.5 \mathrm{~b}$ & $2.2 \mathrm{a}$ & $2.5 \mathrm{a}$ & 2.5 \\
\hline \multicolumn{5}{|l|}{ TE } \\
\hline 0 & 2.6 & 1.8 & $2.2 \mathrm{a}$ & 2.5 \\
\hline 0.02 & 2.5 & 1.7 & $2.1 \mathrm{~b}$ & 2.3 \\
\hline
\end{tabular}

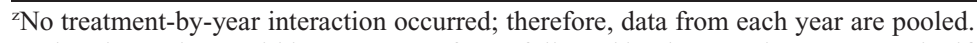

${ }^{y}$ Values in a column within a treatment factor followed by the same letter are not significantly different at $P \leq 0.05$ by protected least significant difference.

Table 5. Clipping yield $\left(\mathrm{g} \cdot \mathrm{m}^{-2}\right)$ of 'L-93' creeping bentgrass in January, February, and May in response to full sunlight and 58\% and 96\% morning, afternoon, and full-day winter shade (December to February, 2004 to 2006) and trinexapac-ethyl (TE; $0.02 \mathrm{~kg} \cdot \mathrm{ha}^{-1}$ ) applications every 2 weeks from 1 Dec. to 31 July 2004 to 2006.

\begin{tabular}{|c|c|c|c|c|}
\hline \multirow{2}{*}{$\begin{array}{l}\text { Treatment factor } \\
\text { Shade }\end{array}$} & Year 1 & Year 2 & \multicolumn{2}{|c|}{ Years 1 and Year 2} \\
\hline & \multicolumn{2}{|c|}{ January } & February $^{z}$ & May $^{z}$ \\
\hline None & $1.56 \mathrm{~b}^{\mathrm{y}}$ & 0.70 & $0.51 \mathrm{~b}$ & 0.67 \\
\hline $58 \%$ morning & $2.47 \mathrm{ab}$ & 0.67 & $0.63 \mathrm{ab}$ & 0.60 \\
\hline $58 \%$ afternoon & $2.83 \mathrm{ab}$ & 0.67 & $0.49 \mathrm{~b}$ & 0.66 \\
\hline $58 \%$ full day & $2.70 \mathrm{ab}$ & 0.61 & $0.47 \mathrm{~b}$ & 0.64 \\
\hline $96 \%$ morning & $1.96 \mathrm{~b}$ & 0.74 & $0.51 \mathrm{~b}$ & 0.61 \\
\hline $96 \%$ afternoon & $3.49 \mathrm{a}$ & 0.67 & $0.56 \mathrm{ab}$ & 0.66 \\
\hline $96 \%$ full day & $3.89 \mathrm{a}$ & 0.54 & $0.76 \mathrm{a}$ & 0.57 \\
\hline \multicolumn{5}{|l|}{ TE } \\
\hline 0 & $3.19 \mathrm{a}$ & $0.74 \mathrm{a}$ & $0.72 \mathrm{a}$ & $0.76 \mathrm{a}$ \\
\hline 0.02 & $2.23 \mathrm{~b}$ & $0.55 \mathrm{~b}$ & $0.40 \mathrm{~b}$ & $0.50 \mathrm{~b}$ \\
\hline
\end{tabular}

${ }^{\mathrm{z}}$ No treatment-by-year interaction occurred; therefore, data from each year are pooled.

${ }^{\mathrm{y}}$ Values in a column within each treatment factor followed by the same letter are not significantly different at $P \leq 0.05$ by protected least significant difference.

Table 6. Total root biomass $\left(\mathrm{g} \cdot \mathrm{m}^{-2}\right)$ and root total nonstructural carbohydrates $\left(\mathrm{mg} \cdot \mathrm{g}^{-1}\right)$ of L93 creeping bentgrass in January and February in response to full sunlight and 58\% and $96 \%$ morning, afternoon, and full-day winter shade and trinexapac-ethyl (TE; $0.02 \mathrm{~kg} \cdot \mathrm{ha}^{-1}$ ) applications every 2 weeks from 1 Dec. to 31 July 2004 to 2006.

\begin{tabular}{lccc}
\hline Treatment factor & \multicolumn{2}{c}{ Root biomass $\left(\mathrm{g} \cdot \mathrm{m}^{-2}\right)$} & Root TNC $\left(\mathrm{mg} \cdot \mathrm{g}^{-1}\right)$ \\
\cline { 2 - 3 } Shade & January & February & February \\
\hline None & 0.79 & $0.89 \mathrm{a}^{\mathrm{z}}$ & $52.6 \mathrm{ab}$ \\
$58 \%$ morning & 0.64 & $0.64 \mathrm{~b}$ & $46.3 \mathrm{~b}-\mathrm{d}$ \\
$58 \%$ afternoon & 0.81 & $0.61 \mathrm{~b}$ & $55.2 \mathrm{a}$ \\
$58 \%$ full day & 0.76 & $0.66 \mathrm{~b}$ & $41.5 \mathrm{~cd}$ \\
$96 \%$ morning & 0.71 & $0.58 \mathrm{~b}$ & $47.9 \mathrm{bc}$ \\
$96 \%$ afternoon & 0.86 & $0.60 \mathrm{~b}$ & $39.9 \mathrm{~d}$ \\
$96 \%$ full day & 0.61 & $0.51 \mathrm{~b}$ & $41.9 \mathrm{~cd}$ \\
TE & & & \\
0 & 0.76 & 0.66 & 45.5 \\
0.02 & 0.72 & 0.62 & 47.5 \\
\hline
\end{tabular}

${ }^{\mathrm{z}}$ Values in a column within each treatment factor followed by the same letter are not significantly different at $P \leq 0.05$ by protected least significant difference.

$25 \%, \approx 17 \%$, and $\approx 12 \%$ higher compared with full sunlight, $58 \%$ shade treatments, and $96 \%$ shade treatments, respectively. Meanwhile, morning or afternoon shade did not influence chlorophyll concentrations. Also, chlorophyll differences were not detected in May.

Trinexapac-ethyl minimally impacted winter and spring chlorophyll concentrations (Table 4). In February, non-TE-treated bent- shade compared with full sunlight. By May, no shoot biomass variations were noted.

Trinexapac-ethyl reduced shoot growth $\approx 38 \%, 79 \%$, and $51 \%$ in January (Years 1 and 2), February, and May, respectively, compared with non-TE-treated plots.

Root biomass and total nonstructural carbohydrates. In February, root biomass under shade, regardless of intensity or duration, was $\approx 49 \%$ lower than full sunlight (Table 6). Morning shade (58\%) root TNC was $19 \%$ lower compared with afternoon shade; however, under $96 \%$ shade, a $20 \%$ root TNC increase was noted for morning shade compared with afternoon shade. Also, fullsunlight root TNC was $27 \%, 32 \%$, and $26 \%$ higher compared with full-day $58 \%$ shade, $96 \%$ afternoon shade, and $96 \%$ full-day shade, respectively. Trinexapac-ethyl did not impact root biomass or root TNC in the winter.

\section{Discussion}

Spring is a period of accelerated growth and carbohydrate accumulation of creeping bentgrass before the onset of summer stress in parts of the transition zone. Therefore, winter shade was evaluated to determine if limiting light availability during winter months would inhibit spring and subsequent summer performance. To the authors' knowledge, this was the first research project initiated to specifically investigate the impact of winter shade on creeping bentgrass putting greens in the southern transition zone with year-round golf play.

Results indicate moderate winter shade may not be a detrimental growth factor for creeping bentgrass putting greens in the transition zone without traffic and other stressful impacts. Typically, $\mathrm{C}_{3}$ plants maintain an appropriate photosynthesis:respiration ratio compared with $\mathrm{C}_{4}$ plants in low-light environments (Wahid and Rasul, 2005). This is possibly the result of the distance between mesophyll and bundle sheath tissues (i.e., anatomical organization) (Sage and McKown, 2006) or efficient sunfleck use (Horton and Neufeld, 1998).

Previous research indicates creeping bentgrass performs well under moderate shade stress. Goss et al. (2002) stated bentgrass showed minimal deleterious effects under $60 \%$ shade, whereas $80 \%$ shade inhibited bentgrass growth and development. Bell and Danneberger (1999) also indicated 'Penncross' creeping bentgrass maintained acceptable color, density, and tissue mass when grown under 69\% shade. Reid (1933) indicated bentgrass grown under heavy shade had a comparable light green color compared with control (full sunlight); however, root growth was restricted. These studies were conducted to coincide with spring season leaf growth and/or fall season leaf drop.

In this study, 3 months of winter shade (except Year 1) consistently showed greater TQ scores and chlorophyll concentrations compared with full-sunlight plots. Studies show that evergreen plants' photosynthetic rates decline when temperatures drop; however, 
chlorophyll continues its light-absorbing properties (Verhoeven et al., 2005). Therefore, photoinhibition will occur unless the xanthophyll cycle and/or antioxidant leaf enzymes minimize excessive light accumulation (Deming-Adams and Adams, 1996). In this study, it appears increasing shade intensity served as a photoprotective role under apparent high light stress, thereby minimizing excess light accumulation in the light-harvesting complexes, which ultimately produces reactive oxygen species. Limited research examining the role of xanthophyll pigments in turfgrasses exists. Bell and Danneberger (1999) noted in a field study that bentgrass violaxanthin concentration decreased with increasing shade stress, whereas other pigment concentrations remained constant. McElroy et al. (2006), in a greenhouse study, reported carotenoid (zeaxanthin, antheraxanthin, violaxanthin, neoxanthin, epoxylutein, and $\beta$-carotene) concentrations decreased as low-light intensity duration increased. Both of these studies examined carotenoid concentrations during favorable growing temperatures for bentgrass. Future studies investigating xanthophyll activity of coolseason turfgrasses under winter shade is warranted to further clarify the relationship between winter shade impact and creeping bentgrass performance. Differences between $96 \%$ full-day shade in Year 1 and 2 may be partially explained by minimum temperature differences in January. The second half of January was greater than $5{ }^{\circ} \mathrm{C}$ colder in Year 1 compared with the second half of January in Year 2. Also, no minimum temperature variations in January were noted in Year 2; however, minimum temperature fluctuated by greater than $10{ }^{\circ} \mathrm{C}$ in Year 1. It appears temperature fluctuation in January (Year 1) negatively affected 'L-93' creeping bentgrass performance under $96 \%$ shade. No differences in precipitation occurred over this 2year field study (data not shown); therefore, it appears this yearly fluctuation is independent of moisture availability.

Although TE typically enhances coolseason turfgrass in shade (Goss et al., 2002; Steinke and Stier, 2003; Tegg and Lane, 2004), this study indicates TE applied every 2 weeks during winter negatively impacted creeping bentgrass growth and color. Creeping bentgrass growth slowed as a result of cool winter temperatures; therefore, applying TE, a GA-inhibiting PGR that slows growth, further reduced growth and discolored creeping bentgrass. Other studies on warm-season turfgrasses have noted surface discoloration and density decrease if TE is applied during periods below an optimal growth temperature range (Fagerness and Yelverton, 2000; McCullough et al., 2006, 2007). Also, Gardner and Wherley (2005) reported TE applied every 6 weeks decreased visual TQ and density of cool-season turfgrasses under shade stress. Greater intervals between winter TE applications or reduced rates may have been more beneficial. Beasley et al. (2007) noted TE uptake was greatest when temperatures were warm, whereas dissipation rate was reduced with cooler temperatures. Therefore, during cool winter months, applying TE in 2-week intervals is unnecessary and caused bentgrass discoloration. Once shade treatments were removed and temperatures were consistently warm, TE enhanced spring and summer bentgrass performance.

Moderate winter shade was beneficial for parameters measured in this study; however, long-term effects of $96 \%$ shade through spring and into summer may decrease bentgrass visual quality. Although TQ and shoot chlorophyll concentrations increased under 96\% shade in February (Year 2), root mass and root TNC declined compared with fullsunlight. This indicates bentgrass reallocated energy constituents and carbohydrate reserves to shoot tissue to maintain winter green color and continued winter growth instead of carbohydrate conservation. This strategy would presumably be detrimental (i.e., carbohydrate depletion) for sustaining a high-quality putting green during summer stress if $96 \%$ shade continued through the spring. However, Beard and Daniel (1966) noted temperature reductions enhanced 'Old Orchard' creeping bentgrass root activity. Thus, partial spring and summer shade, which reduces canopy and soil temperatures, may improve creeping bentgrass survival in the hot, humid transition zone by initiating new summer root growth as long as a prudent disease control program is initiated.

Trinexapac-ethyl did not impact root biomass. This is in general agreement with results by Fagerness and Yelverton (2000) and McCullough et al. (2007). Although TE did not increase root TNC in this study, Ervin and Zhang (2007) reported increases in bentgrass leaf carbohydrate content after sequential TE applications in a greenhouse study. Goss et al. (2002) reported TE-treated creeping bentgrass increased carbohydrate content under $80 \%$ shade stress compared with non-TE-treated creeping bentgrass. Also, Goss et al. (2002) observed significant increases in shoot carbohydrate content compared with root carbohydrate content of creeping bentgrass when grown under $80 \%$ shade. In our study, sampling shoot TNC may have been more appropriate than root TNC as a shade stress indicator.

Overall, morning or afternoon shade minimally impacted parameters measured. Results agree with Bell and Danneberger (1999), which stated shade duration rather than diurnal shade was more detrimental to 'Penncross' creeping bentgrass growth under $80 \%$ or $100 \%$ shade. However, $58 \%$ and $96 \%$ diurnal shade impact on parameters measured was inconsistent. For example, 58\% morning shade reduced root TNC, whereas $96 \%$ morning shade increased root TNC compared with afternoon shade. Bunnell et al. (2005a) noted afternoon shade decreased root carbohydrate content of 'TifEagle' bermudagrass compared with morning shade. However, Bell and Danneberger (1999) did not detect any bentgrass carbohydrate content variation in response to diurnal shade. It appears time of shade may be more critical for bermudagrass putting greens rather than cool-season putting greens. Future research of other turfgrass species' and cultivars' response to morning or afternoon shade would prove beneficial.

In summary, moderate winter shade did not cause stresses rather enhanced bentgrass growth, whereas few differences were noted between morning or afternoon winter shade in the transition zone. Trinexapac-ethyl applications on creeping bentgrass putting greens should not be applied during winter months under shade conditions. Regardless of winter stress, all plots fully recovered by early spring because TQ scores were above the acceptable threshold of 6 . Therefore, this study suggests that winter shade is not a contributing factor for creeping bentgrass summer decline. Future studies should investigate creeping bentgrass performance and responses under winter shade, including traffic factors and lighter rates of TE plus other influential environmental factors. Also, other creeping bentgrass cultivars as well as other turfgrass species, including winter overseeding species winter shade performance, should be evaluated to determine if a reduced light environment inhibits growth during winter months.

\section{Literature Cited}

Adams, R., E. Kerber, K. Pfister, and E.W. Weiler. 1992. Studies on the action of the new growth retardant CGA163935 (Primo), p. 818-827. In: Karssen, C.M., L.C. van Loon, and D. Vreugdenhil (eds.). Progress in plant growth regulation. Kluwer, Dordrecht, The Netherlands.

Arnon, D.I. 1949. Copper enzymes in isolated chloroplasts. Polyphenoloxidases in Beta Vulgaris. Plant Physiol. 24:241-249.

Baldwin, C.M., H. Liu, L.B. McCarty, H. Luo, and J.E. Toler. 2009. Nitrogen and plant growth regulator influence of 'Champion' bermudagrass putting green under reduced sunlight. Agron. J. 101:75-81.

Baldwin, C.M., H. Liu, L.B. McCarty, H. Luo, J. Toler, and S.H. Long. 2008. Winter month foot and equipment traffic impacts on a 'L-93' creeping bentgrass putting green. HortScience 43:922-926.

Beard, J.B. 1965. Factors in the adaptation of turfgrasses to shade. Agron. J. 57:457-459.

Beard, J.B. 1969. Turfgrass shade adaptation, $p$ 273-282. In: Roberts, E.C. (ed.). Proc. of the 1 st Int. Turfgrass Res. Conf. Alf Smith and Co., Bradford, UK

Beard, J.B. and W.H. Daniel. 1966. Relationship of creeping bentgrass (Agrostis palustris Huds.) root growth to environmental factors in the field. Agron. J. 58:337-339.

Beasley, J.S., B.E. Branham, and L.A. Spomer. 2007. Plant growth regulators alter kentucky bluegrass canopy leaf area and carbon exchange. Crop Sci. 47:757-764.

Bell, G. and T.K. Danneberger. 1999. Temporal shade on creeping bentgrass turf. Crop Sci. 39:1142-1146.

Bunnell, B.T., L.B. McCarty, R.B. Dodd, H.S. Hill, and J.J. Camberato. 2002. Creeping bentgrass growth response to elevated soil carbon dioxide. HortScience 37:367-370.

Bunnell, B.T., L.B. McCarty, J.E. Faust, W.C. Bridges, Jr., and N.C. Rajapakse. 2005a. Quantifying a daily light integral requirement of a 
'TifEagle' bermudagrass golf green. Crop Sci. 45:569-574.

Bunnell, B.T., L.B. McCarty, and W.C. Bridges, Jr. 2005b. 'TifEagle' bermudagrass responses to growth factors and mowing height when grown at various hours of sunlight. Crop Sci. 45:575-581.

Bunnell, B.T., L.B. McCarty, and H.S. Hill. 2004. Soil gas, temperature, matric potential, and creeping bentgrass growth response to subsurface air movement on a sand-based golf green. HortScience 39:415-419.

Deming-Adams, B. and W.W. Adams, III. 1996. Xanthophyll cycle and light stress in nature: Uniform plant response to excess direct sunlight among higher plant species. Planta 198:460-470.

Dernoeden, P.H. 2002. Creeping bentgrass management: Summer stresses, weeds, and selected maladies. John Wiley \& Sons, Hoboken, NJ.

Dudeck, A.E. and C.H. Peacock. 1992. Shade and turfgrass culture, p. 269-284. In: Waddington, D.V., R.N. Carrow, and R.C. Shearman (eds.). Turfgrass. Agron. Monogr. 32. ASA, CSSA, and SSSA, Madison, WI.

Ervin, E.H. and X. Zhang. 2007. Influence of sequential trinexapac-ethyl applications on cytokinin content in creeping bentgrass, kentucky bluegrass, and hybrid bermudagrass. Crop Sci. 47:2145-2151.

Ervin, E.H., X. Zhang, S.D. Askew, and J.M. Goatly, Jr. 2004. Trinexapac-ethyl, propiconazole, iron, and biostimulant effects on shaded creeping bentgrass. HortTechnology 14:500-506.

Fagerness, M.J. and F.H. Yelverton. 2000. Tissue production and quality of Tifway bermudagrass, as affected by seasonal applications of trinexapac-ethyl. Crop Sci. 40:493-497.

Feng, Y., D.M. Stoeckel, E. van Santen, and R.H. Walker. 2002. Effects of subsurface aeration and trinexapac-ethyl application on soil microbial communities in a creeping bentgrass putting green. Biol. Fertil. Soils 36:456460.

Fu, J. and B. Huang. 2003. Growth and physiological response of creeping bentgrass to elevated night temperature. HortScience 38:299-301.

Gardner, D.S. and B.G. Wherley. 2005. Growth response of three turfgrass species to nitrogen and trinexapac-ethyl in shade. HortScience 40:1911-1915.

Goss, R.M., J.H. Baird, S.L. Kelm, and R.N. Calhoun. 2002. Trinexapac-ethyl and nitrogen effects on creeping bentgrass grown under reduced light conditions. Crop Sci. 42:472479.

Guertal, E.A., E. van Santen, and D.Y. Han. 2005. Fan and syringe application for cooling bentgrass greens. Crop Sci. 45:245-250.

Hiscox, J.D. and G.F. Israelstam. 1979. A method for the extraction of chlorophyll from leaf tissue without maceration. Can. J. Bot. 57:1332-1334.

Horton, J.L. and H.S. Neufeld. 1998. Photosynthetic responses of Microstegium vimineum (Trin.) A. Camus, a shade tolerant, $\mathrm{C}_{4}$ grass, to variable light environments. Oecologia 114:11-19.

Huang, B. and H. Gao. 2000. Growth and carbohydrate metabolism of creeping bentgrass cultivars in response to increasing temperatures. Crop Sci. 40:1115-1120.

Liu, X. and B. Huang. 2003. Mowing height effects on summer turf growth and physiological activities for two creeping bentgrass cultivars. HortScience 38:444-448.

McCarty, L.B. 2005. Turfgrasses, p. 37-40. In: McCarty, L.B. (ed.). Best golf course management practices. 2nd Ed. Prentice-Hall, Upper Saddle River, NJ.

McCullough, P.E., H. Liu, L.B. McCarty, and J.E. Toler. 2007. Trinexapac-ethyl application regimes influence growth, quality, and performance bermuda greens and creeping bentgrass putting greens. Crop Sci. 47:2138-2144.

McCullough, P.E., H. Liu, L.B. McCarty, T. Whitwell, and J.E. Toler. 2006. Bermudagrass putting green growth, color, and nutrient partitioning influenced by nitrogen and trinexapacethyl. Crop Sci. 46:1515-1525.

McElroy, J.S., D.A. Kopsell, J.C. Sorochan, and C.E. Sams. 2006. Response of creeping bentgrass carotenoid composition to high and low irradiance. Crop Sci. 46:2606-2612.

Nelson, N. 1944. A photometric adaptation of the Somogyi method for determination of glucose. J. Biol. Chem. 153:375-381.

Qian, Y.L. and M.C. Engelke. 1999. Influence of trinexapac-ethyl on diamond zoysiagrass in a shaded environment. Crop Sci. 39:202-208.

Qian, Y.L., M.C. Engelke, M.J.V. Foster, and S.M. Reynolds. 1998. Trinexapac-ethyl restricts shoot growth and improves quality of Diamond zoysiagrass under shade. HortScience 33:1019-1022.

Reid, M.E. 1933. Effects of shade of the growth of velvet bent and metropolitan creeping bent. USGA Green Sect. 13:131-135.

Rodriguez, I.R., L.B. McCarty, J.E. Toler, and R.B. Dodd. 2005. Soil $\mathrm{CO}_{2}$ concentration effects on creeping bentgrass grown under various soil moisture and temperature conditions. HortScience 40:839-841.

Sage, R.F. and A.D. McKown. 2006. Is $\mathrm{C}_{4}$ photosynthesis less phenotypically plastic than $\mathrm{C}_{3}$ photosynthesis? J. Expt. Bot. 57:303-317.

Somogyi, M. 1952. Notes on sugar determination. J. Biol. Chem. 195:19-23.

Steinke, K. and J.C. Stier. 2003. Nitrogen selection and growth regulator applications for improving shaded turf performance. Crop Sci. 43:1399-1406.
Stier, J.C. and J.N. Rogers, III. 2001. Trinexapacethyl and iron effects on supina and kentucky bluegrasses under low irradiance. Crop Sci. 41:457-465.

Tan, Z.G. and Y.L. Qian. 2003. Light intensity affects gibberellic acid content in kentucky bluegrass. HortScience 38:113-116.

Tegg, R.S. and P.A. Lane. 2004. Shade performance of a range of turfgrass species improved by trinexapac-ethyl. Aust. J. Exp. Agr. 44:939945.

United States Golf Association Green Section Staff. 1993. USGA recommendations for a method of putting green construction. The 1993 Revision. USGA Green Section Record 31:1-3.

Vargas, J.M. and J.B. Beard. 1981. Shade environment-disease relationships of kentucky bluegrass cultivars, p. 391-395. In: Sheard, R.W. (ed.). Proc. 4th Int. Turfgrass Res. Conf., Guelph, ON, Canada; 19-23 July 1981. Int. Turfgrass Soc., and Ontario Agric. Coll. Univ. of Guelph, Guelph, Ontario, Canada.

Verhoeven, A.S., A. Swanberg, M. Thao, and J. Whiteman. 2005. Seasonal changes in leaf antioxidant systems and xanthophyll cycle characteristics in Taxus Xmedia growing in sun and shade environments. Physiol. Plant. 123:428-434.

Wahid, A. and E. Rasul. 2005. Photosynthesis in leaf, stem, flower, and fruit, p. 479-497. In: Pessarakli, M. (ed.). Handbook of photosynthesis. 2nd Ed. Taylor and Francis Group, LLC, Boca Raton, FL.

Waltz, F.C., Jr. and T. Whitwell. 2005. Trinexapacethyl effects on total nonstructural carbohydrates of field-grown hybrid bermudagrass. Int. Turfgrass Soc. Res. J. 10:899-903.

Westhafer, M.A., J.T. Law, Jr., and D.T. Duff. 1982. Carbohydrate quantification and relationships with $\mathrm{N}$ nutrition in cool-season turfgrass. Agron. J. 74:270-274.

White, R.H. 2004. Environment and culture affect bermudagrass growth and decline. USGA Greens Section Record. 42:21-24.

Williams, D.W., A.J. Powell, Jr., C.T. Dougherty, and P. Vincelli. 1998. Separation and quantization of the sources of dew on creeping bentgrass. Crop Sci. 38:1613-1617.

Williams, D.W., A.J. Powell, Jr., P. Vincelli, and C.T. Dougherty. 1996. Dollar spot on bentgrass influenced by displacement of leaf surface moisture, nitrogen, and clipping removal. Crop Sci. 36:1304-1309.

$\mathrm{Xu}, \mathrm{Q}$. and B. Huang. 2000. Growth and physiological responses of creeping bentgrass to changes in air and soil temperatures. Crop Sci. 40:1363-1368.

Xu, Q. and B. Huang. 2001. Lowering soil temperature improves creeping bentgrass growth under heat stress. Crop Sci. 41:1878-1883. 